\title{
Genes for Resistance to Powdery Mildew Races 1 and 2U.S. in Melon PI 313970
}

\author{
James D. McCreight \\ U.S. Department of Agriculture, Agricultural Research Service, U.S. \\ Agricultural Research Station, 1636 E. Alisal Street, Salinas, CA 93905
}

\author{
Additional index words. cantaloupe, disease, resistant blister, genetics, germplasm, linkage, \\ Cucumis melo, muskmelon, Sphaerotheca fuliginea, Sphaerotheca fusca, Podosphaera \\ xanthii
}

\begin{abstract}
Powdery mildew is a major problem in melon (Cucumis melo L.) production worldwide. Three genes for resistance to Sphaerotheca fuliginea (Schlecht. ex Fr.) Poll. race 1 and race 2 U.S. were identified in growth chamber and greenhouse tests in the cross of PI 313970 x 'Top Mark'. A recessive gene conditioned resistance of true leaves to race 1. A recessive gene appeared to condition resistance of cotyledons to race $2 \mathrm{U}$.S., although a second recessive gene may be involved. A semi-dominant gene conditioned resistance of true leaves to race $2 \mathrm{U}$.S. Limited data suggested linkage of the recessive gene for resistance to race 1 and the semi-dominant gene for resistance to race $2 \mathrm{U}$.S. The resistance reaction of PI 313970 to infection of true leaves by race 2U.S. included water-soaked spots and resistant blisters, but segregation data for the resistant blister reaction were inconclusive. Allelic relationships of these genes with previously reported melon powdery mildew resistance genes remain to be determined.
\end{abstract}

Powdery mildew is a major problem in melon (Cucumis melo L.) production worldwide. The disease may be caused by one or two fungi: Sphaerotheca fuliginea (Schlecht. ex Fr.) Poll. and Erysiphe cichoracearum DC ex Merat. Seven races (including two variants of race 2: 2France and 2U.S.) of S. fuliginea and two races of E. cichoracearum have been reported, and numerous genes for resistance have been described in 18 sources of resistance (Pitrat et al., 1998). New races may appear in response to the introduction of resistance genes (Hosoya etal., 2000). Therefore, sources of new powdery mildew resistance genes are always of interest to melon breeders and growers.

Melon PI 313970 was highly resistant to powdery mildew incited by $S$. fuliginea race 2U.S. during greenhouse studies on the inheritance of its resistance to lettuce infectious yellows crinivirus (LIYV). During the LIYV tests when powdery mildew-susceptible genotypes were heavily infected with powdery mildew, PI 313970 exhibited water-soaked spots and raised blisters. Blisters on leaves in one test were found to harbor powdery mildew and produced spores after placement in a moist box overnight (unpublished). The blisters on PI 313970 were similar to those described on hops, Humulus lupulus L., in response to powdery mildew incited by Sphaerotheca humuli DC. (Burr) (Royle, 1978; Salmon, 1917). There are two types of resistance to powdery mildew in

\footnotetext{
Received for publication 13 Nov. 2001. Accepted for publication 3 Nov. 2002. The author thanks Patti Fashing for assistance in this research. Mention of a proprietary product in this paper does not constitute endorsement of the product by the U.S. Dept. of Agriculture.
}

hops: 1) race specific immunity and 2) resistant blister (previously called semi-immunity) to any isolate (race) of S. humuli (Royle, 1978). Resistant blisters are expressed in late stages of infection; leaves on resistant plants produce raised blisters with small amounts of mycelia and conidiophores that soon die to leave small patches of dead epidermal cells (Liyanage et al., 1973; Royle, 1978; Salmon, 1919).The blisters on melon PI 313970 in response to $S$. fuliginea race 2U.S. were similar to the resistant blisters on hops: they did not appear on young leaves but appeared when susceptible genotypes were heavily infected, and they were restricted in size and sporulation. Inheritance of the resistant blister reaction and its race specificity are unknown. This report describes the resistant reactions of PI 313970 to $S$. fuliginea races 1 and 2U.S. and their inheritance.

\section{Material and Methods}

Plant materials. The PI 313970 seeds used in these tests were derived via sib- and selfpollination in the greenhouse from melon line 90625, which had been derived from a sample of seeds received by the U.S. National Plant Germplasm System (NPGS) in 1966. This population of PI 313970 represents a subset of the variation present in the population maintained by NPGS (McCreight, 2000b). 'PMR 5', PI 124111, and PI 124112 seeds were similarly produced. Seeds of 'Top Mark' and 'PMR 45' were obtained from commercial sources. Reciprocal $F_{1}$ and $F_{2}$ families, and backcross families of the $F_{1}$ generation with the resistant (PI 313970) and susceptible ('Top Mark') parents were included in the inheritance tests.

Seeds were germinated on moistened paper towels in moist boxes at $25^{\circ} \mathrm{C}$ with 12 -h photoperiods. They were transplanted into plastic pots $(10 \times 10 \times 10 \mathrm{~cm}$ deep; one seedling/pot $)$ at the cotyledon stage of growth and grown as previously described (McCreight, 2000a) . Plants were then placed in a growth chamber (race 1) or greenhouse (race 2U.S.). Plants were watered daily (greenhouse) or weekly (growth chamber) with dilute (1:100) $20 \mathrm{~N}-20 \mathrm{P}-20 \mathrm{~K}$ fertilizer solution. No pesticides were applied to the seedlings in the growth chamber. The growth chamber was set to operate at $25^{\circ} \mathrm{C}$ with a 12-h photoperiod (PAR $\left.1600 \mu \mathrm{mol} \cdot \mathrm{m}^{-2} \cdot \mathrm{s}^{-1}\right)$. In the first greenhouse test, seedlings were treated with Marathon for insect control. No pesticides were used in subsequent greenhouse tests.

Pathogen culture and race identification. Race 2U.S. occurs throughout the year on various melon cultigens and 'Grey Zucchini' squash (Cucurbita pepo L.) in the Salinas, Calif., greenhouse in which these race 2U.S. tests were carried out. Race 1 was obtained from the race 2 U.S. population via single spore transfer to cotyledons of 'Marketer' cucumber (Cucumis sativus L.) in axenic culture in a growth chamber at $25^{\circ} \mathrm{C}$ and 12 -h photoperiod. The pure culture of race 1 was then transferred to 'Marketer' cucumber plants that had been germinated and grown in the growth chamber in which the race 1 tests were subsequently conducted. Test plants in the growth chamber and greenhouse were inoculated using air circulation fans to disperse spores from source plants to test plants that were placed around and among the source plants.

Species identification of the powdery mildew isolates was confirmed by examination of conidia for the presences of fibrosin bodies and production of forked germ tubes (Ballantyne, 1975; Kable and Ballantyne, 1963). Race determinations were made in each test based on the reaction of one or more known race differentials (Pitrat et al., 1998). In the first growth chamber and greenhouse tests, only 'PMR 45' was included. In subsequent tests, 'PMR 45', 'PMR 5', PI 124111, and PI 124112 were included. 'Edisto 47', WMR 29, and PI 414723 were grown in the greenhouse for cross pollination with PI 313970, and although they were not included in the race 2U.S. tests, their reactions to powdery mildew infection were noted.

Experiment design, data collection, and analysis. In the first tests using race 1 and race 2U.S. plants were randomized in single blocks. Plants were arranged in three blocks in the subsequent tests with unequal numbers of plants per entry in each block. For example, in each replication there were two or three plants of the parents and differentials, while there were 20 plants per $F_{2}$ family. Plants resistant to race 1 in one test were moved from the growth chamber to the greenhouse for subsequent evaluation of their resistance to race 2U.S. The race 2 U.S. disease reaction data for these plants were for true leaves only.

Data were collected from hypocotyls, cotyledons, and true leaves, up to the fifth leaf with the exception of the first race 2U.S. test in which a single rating of the whole plant was recorded. Infection of cotyledons and true leaves as evidenced by mycelial growth and sporulation was rated on a 1 to 9 scale as follows: $1=$ no 
evidence of disease $; 2=$ trace of hyphae; $3=$ hyphae restricted; 4 = few colonies present, sporulation; $5=$ scattered colonies, sporulation; $6=$ numerous colonies, sporulation; $7=$ about $50 \%$ of adaxial surface covered with hyphae and spores, few colonies on abaxial surface, abundant sporulation; $8=$ greater than $50 \%$ of adaxial surface covered with hyphae and spores, scattered colonies on abaxial surface, abundant sporulation; $9=$ greater than $75 \%$ of adaxial surface covered with hyphae and spores, numerous or coalesced colonies on abaxial surface.

Hypocotyls were rated on the same scale with the exception, of course, for lack of adaxial and abaxial surfaces. A $3 \times$ magnifier was used to aid in discerning classes 1 through 6 . Water-soaked spots and resistant blisters were noted as either present or absent. Data were recorded weekly following the first appearance of powdery mildew on the seedlings for a period of 7 weeks.

A composite rating for each plant was developed using data from one or more leaves evaluated on one or more dates. Race 1 data were combined into four groups for analysis: $\mathrm{R}$ $(\text { resistant })_{1}=$ class $1 ; \mathrm{R}$ (resistant $)_{2,3}=$ classes $2+3$; I (intermediate $)_{4-6}=$ classes $4+5+6$; and $S$ (susceptible) $)_{7-9}=$ classes $7+8+9$. Race 2U.S. data were combined into three groups for analysis: $\mathrm{R}$ (resistant) $)_{1-3}=$ classes $1+2+3$; I (intermediate) $)_{4-6}=$ classes $4+5+6$; and S (susceptible $)_{7-9}=$ classes $7+8+9$. The groups were combined for chi-square analyses as appropriate for mono- and dihybrid segregations. Yates correction was applied to chi-square analysis where the expected number of segregants in any class was <20 (Yates, 1931).

\section{Results}

Race 1. Hypocotyls and cotyledons of 'Top Mark' were highly susceptible to race 1 (data not shown). In contrast, 'PMR 45' and 'PMR 5' were highly resistant at these stages of growth, i.e., no evidence of powdery mildew infection. PI 124111 hypocotyls were similarly resistant, but the cotyledons of one of six plants were rated intermediate for powdery mildew infection. PI 124112 hypocotyls were also highly resistant, but cotyledons of two plants were rated intermediate and those of another plant (one of six) were susceptible to race 1 . Hypocotyls and cotyledons of PI 313970 were susceptible to race 1 . Hypocotyls of some plants of PI 313970 and 'Top Mark' escaped infection, and escapes were frequently observed in their $F_{1}$ and segregating generations, but there was no clear genetic segregation in the $\mathrm{F}_{2}$ or $\mathrm{BC}$ generations. Cotyledons in $\mathrm{F}_{1}$ and segregating generations were uniformly susceptible to race 1.

'Top Mark' was highly susceptible to race 1 at the true leaf stage, while the race differentials were, with the exception of PI 124112, highly resistant to race 1 (Table 1 ). Restricted colonies characterized by sparse mycelial growth and without apparent sporulation occurred on PI 124112, whereas 'PMR 45', 'PMR 5', and PI 124111 were essentially free of infection by race 1. PI 313970 was similar to PI 124112.
True leaves of the $F_{1}$ 'Top Mark' x PI 313970 were susceptible while the $\mathrm{F}_{2}$ segregated in a 3 susceptible $\left(\mathrm{I}_{4-6}+\mathrm{S}_{7-9}\right): 1$ resistant $\left(\mathrm{R}_{1}+\right.$ $\mathrm{R}_{2,3}$ ) ratio (Table 1 ), which suggested that the resistance of true leaves to race 1 in PI 313970 was conditioned by a single recessive gene. The backcross data were consistent with this model. The $\mathrm{BC}_{1 \mathrm{~S}}$ was mostly susceptible with a few plants rated intermediate, and the $\mathrm{BC}_{1 \mathrm{R}}$ segregated in accordance with a 1 susceptible : 1 resistant ratio (Table 1).

Race 2U.S. Infection of hypocotyls and cotyledons was not observed in the first test for resistance to race 2U.S. due to apparent insecticide toxicity. Four of six 'PMR 45' plants in the second test had infected hypocotyls, while the hypocotyl of only one of nine 'Top Mark' plants was infected (data not shown). None of the 'PMR 5', PI 124111, or PI 124112 plants (six each) were susceptible to hypocotyl infection, whereas two of $12 \mathrm{PI}$ 313970 plants were infected (data not shown). Although hypocotyls of 18 of $24 \mathrm{~F}_{1}$ 'Top Mark' X PI 313970 plants were susceptible, there was no obvious pattern of segregation in the $F_{2}$ or $\mathrm{BC}_{1}$ generations.

'Top Mark' and 'PMR 45' cotyledons were infected in the second race 2U.S. test (Table 1). Although some of the plants of 'PMR 5', PI 124111, PI 124112, and PI 313970 showed visible cotyledon infection they were rated as resistant (Table 1). The $\mathrm{F}_{1}$ 'Top Mark' x PI 313970 was susceptible to cotyledon infection. The $\mathrm{F}_{2}$ segregation fitted better to the 1 resistant : 15 susceptible ratio expected in the case of two recessive genes than to the 1 resistant : 3 susceptible ratio expected in the case of a single recessive gene (Table 1). The $\mathrm{BC}_{1 \mathrm{~S}}$ was susceptible with the exception of one individual, which would be expected with either a single or a two-gene model. The $\mathrm{BC}_{1 \mathrm{R}}$ segregation was a close fit to the 1 resistant : 1 susceptible ratio expected in the case of a single recessive gene, but did not fit the 1 resistant : 15 susceptible ratio expected in the case of two recessive genes (Table 1).

True leaves of 'Top Mark' and 'PMR 45' were highly susceptible to race 2U.S. (Table 1). 'Edisto 47' and PI414723 were susceptible, and WMR 29 was heterogeneous (data not shown) as expected (McCreight et al., 1987; Pitrat et al., 1998). PI 124111,PI 124112, and PI 313970 were highly resistant.

True leaves of the $F_{1}$ 'Top Mark'x PI313970 exhibited an intermediate level of resistance to race 2U.S., although five of 34 plants were rated susceptible (Table 1). The $\mathrm{F}_{2}$ segregated in an acceptable fit to a 1 resistant : 2 intermediate : 1 susceptible ratio (Table 1 ). In the $\mathrm{BC}_{1 \mathrm{~S}}$, one family segregated in an acceptable fit to the expected 1 intermediate : 1 susceptible ratio, while a second $\mathrm{BC}_{1 \mathrm{~S}}$ family did not (Table 1). The single $\mathrm{BC}_{1 \mathrm{R}}$ segregated in an acceptable fit to the expected 1 resistant: 1 intermediate ratio (Table 1). These results suggest that a single semi-dominant gene conditioned resistance of true leaves to race 2U.S. in PI 313970.

The poor fit of the cotyledon data in the $\mathrm{F}_{2}$ precluded use of the dihybrid $\mathrm{F}_{2}$ data for linkage analysis of the cotyledon and true leaf reactions to race 2U.S. based on a single recessive gene model. The $\mathrm{BC}_{1 \mathrm{R}}$ segregated 3 resistant leaf, susceptible cotyledon : 16 resistant leaf, resistant cotyledon : 14 intermediate leaf, susceptible cotyledon : 3 intermediate leaf, resistant cotyledon, an unacceptable fit to the expected 1:1:1:1 dihybrid ratio $\left(\chi^{2}=13.7\right.$ with Yates correction, $P=0.006)$. The estimated recombination fraction was $0.17 \pm 0.06$ based on this small sample.

Even though the cotyledon data in the $\mathrm{F}_{2}$ fit the expected ratio for the two recessive gene model, the limited size of the data set $(n=60)$ precluded linkage analysis of the cotyledon and true leaf reactions to race 2U.S. where there are 64 unique theoretical genotypes. The unacceptable fit of the cotyledon data in the $B C_{R}$ precluded use of the dihybrid $B_{R}$ data for linkage analysis.

The resistant blister reaction to race 2U.S. exhibited by PI 313970 during the LIYV tests was also present in these tests. In the first test, where resistant blisters were confounded with necrotic spots and water-soaked spots the segregation data (not shown) suggested a dominant gene. In the second test, six plants each of 'Top Mark', 'PMR 45', and 'PMR 5' did not exhibit resistant blisters, but one of six plants of PI 124112 exhibited a resistant blister reaction. All six plants of PI 124111 and 12 plants of PI 313970 exhibited resistant blisters. The $F_{1}$ 'Top Mark' XPI313970 did not exhibit resistant blisters and the $F_{2}$ segregated 57 no resistant blister : 3 resistant blister $\left(\chi^{2}=0.02\right.$ with Yates correction, $P=0.90$ ), which suggested that two recessive genes conditioned this reaction to infection by race 2U.S. in PI 313970. The $\mathrm{BC}_{1 \mathrm{~s}}$ did not exhibit blisters, which was consistent with the $F_{1}$ and $F_{2}$ data. In contradiction, the $\mathrm{BC}_{1 \mathrm{R}}$ segregated in a close fit to a 27 blister : 9 no blister $\left(\chi^{2}=0.04\right.$ with Yates correction, $P=$ 0.86 ), expected if a dominant gene conditioned the resistant blister reaction.

Independence of resistance to race 1 and race 2 U.S. As expected, 'PMR 45' $(\mathrm{n}=6)$, which was resistant to race 1 , was highly susceptible to race 2U.S. Likewise, 'PMR 5' ( $\mathrm{n}=5)$, PI $124111(\mathrm{n}=6)$, PI 124112 ( =6), and PI $313970(n=12)$, which were all resistant to race 1 , were rated resistant to race 2U.S. The $B_{1 \mathrm{R}}$ segregated 19 resistant $\left(\mathrm{R}_{1}\right.$ $\left.+\mathrm{R}_{2,3}\right): 16$ susceptible $\left(\mathrm{I}_{4-6}+\mathrm{S}_{7-9}\right)$ plants in response to infection by race 1 , an acceptable fit to the expected $1: 1$ ratio $\left(\chi^{2}=0.11\right.$ with Yates correction, $P=0.74)$. Upon exposure to race 2 U.S., the 19 race 1 -resistant $\mathrm{BC}_{1 \mathrm{R}}$ plants segregated 16 resistant $\left(\mathrm{R}_{1-3}\right): 3$ intermediate $\left(\mathrm{I}_{4-6}\right)$ plants, an unacceptable fit to the expected $1: 1$ ratio $\left(\chi^{2}=7.56\right.$ with Yates correction, $P$ $=0.008$ ) where two independent genes were responsible for resistance to the two races. These limited data suggest linkage between the genes for resistance of true leaves to races 1 and 2U.S in PI 313970.

\section{Discussion}

PI 313970 is a useful source of resistance genes. It possesses a single dominant gene for resistance to LIYV (McCreight, 2000a) and is also reported to have useful levels of resistanceto Bemisia tabaci,Diaphania hyalinata, and 


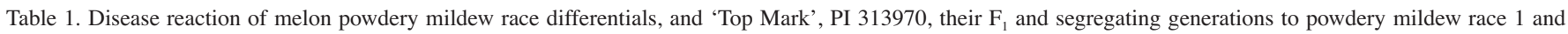
race $2 \mathrm{U} . \mathrm{S}$.

\begin{tabular}{|c|c|c|c|c|c|c|c|c|c|c|c|c|c|c|c|c|c|c|c|}
\hline \multirow[b]{4}{*}{ Entry } & \multicolumn{7}{|c|}{ Race 1} & \multicolumn{12}{|c|}{ Race 2U.S. } \\
\hline & \multicolumn{7}{|c|}{ True leaves } & \multicolumn{6}{|c|}{ Cotyledons } & \multicolumn{6}{|c|}{ True leaves } \\
\hline & \multirow{2}{*}{$\begin{array}{l}\text { Pheno- } \\
\text { type }^{\text {w }}\end{array}$} & \multicolumn{4}{|c|}{ Disease reaction $^{2}$} & \multirow{2}{*}{$\begin{array}{c}\text { Expected } \\
\text { ratio }^{\mathrm{v}}\end{array}$} & \multirow[b]{2}{*}{$P^{\mathrm{u}}$} & \multirow{2}{*}{$\begin{array}{l}\text { Pheno- } \\
\text { type }^{w}\end{array}$} & \multicolumn{3}{|c|}{ Disease reaction $^{y}$} & \multirow{2}{*}{$\begin{array}{c}\text { Expected } \\
\text { ratio }^{\prime}\end{array}$} & \multirow[b]{2}{*}{$P$} & \multirow{2}{*}{$\begin{array}{l}\text { Pheno- } \\
\text { type }^{w}\end{array}$} & \multicolumn{3}{|c|}{ Disease reaction $^{\mathrm{y}}$} & \multirow{2}{*}{$\begin{array}{c}\text { Expected } \\
\text { ratio }^{t}\end{array}$} & \multirow[b]{2}{*}{$P$} \\
\hline & & $\mathrm{R}_{1}$ & $\mathrm{R}_{2,3}$ & $\mathrm{I}_{4-6}$ & $\overline{\mathrm{S}_{7-9}}$ & & & & $\mathrm{R}_{1-3}$ & $\mathrm{I}_{4-6}$ & $\mathrm{~S}_{7-9}$ & & & & $\mathrm{R}_{1-3}$ & $\mathrm{I}_{4-6}$ & $\overline{\mathrm{S}_{7-9}}$ & & \\
\hline$\overline{\text { PMR 45 }}$ & $\mathrm{R}$ & 15 & 1 & 0 & 0 & & & $\mathrm{~S}$ & 0 & 0 & 6 & & & $\mathrm{~S}$ & 0 & 0 & 16 & & \\
\hline PMR 5 & $\mathrm{R}$ & 6 & 0 & 0 & 0 & & & $\mathrm{R}$ & 5 & 0 & 1 & & & $\mathrm{R}$ & 5 & 1 & 0 & & \\
\hline PI 124111 & $\mathrm{R}$ & 5 & 1 & 0 & 0 & & & $\mathrm{R}$ & 4 & 2 & 0 & & & $\mathrm{R}$ & 6 & 0 & 0 & & \\
\hline PI 124112 & $\mathrm{R}$ & 0 & 6 & 0 & 0 & & & $\mathrm{R}$ & 5 & 1 & 0 & & & $\mathrm{R}$ & 6 & 0 & 0 & & \\
\hline Top Mark (TM) & $\mathrm{S}$ & 0 & 0 & 0 & 11 & & & $\mathrm{~S}$ & 0 & 1 & 8 & & & $\mathrm{~S}$ & 0 & 0 & 19 & & \\
\hline PI 313970 (PI) & $\mathrm{R}$ & 0 & 21 & 1 & 0 & & & $\mathrm{R}$ & 10 & 2 & 0 & & & $\mathrm{R}$ & 22 & 0 & 0 & & \\
\hline $\mathrm{F}_{1} \mathrm{TM} \times \mathrm{PI}$ & & 0 & 0 & 9 & 24 & & & & 0 & 2 & 22 & & & & 0 & 29 & 5 & $0: 1: 0$ & \\
\hline $\mathrm{F}_{2} \mathrm{TM} \times \mathrm{PI}$ & & 1 & 22 & 28 & 69 & $1: 3$ & 0.15 & & 7 & 9 & 44 & $\begin{array}{c}1: 3 \\
1: 15\end{array}$ & $\begin{array}{l}0.03^{\mathrm{s}} \\
0.15^{\mathrm{s}}\end{array}$ & & 35 & 55 & 26 & $1: 2: 1$ & 0.44 \\
\hline $\mathrm{BC}_{1 \mathrm{~S}}(\mathrm{TM} \times \mathrm{PI})$ & & 0 & 0 & 9 & 45 & $0: 1$ & & & 1 & 3 & 20 & $0: 1$ & & & $\begin{array}{l}0 \\
1\end{array}$ & $\begin{array}{r}12 \\
7\end{array}$ & $\begin{array}{l}12 \\
22\end{array}$ & $\begin{array}{l}0: 1: 1 \\
0: 1: 1\end{array}$ & $\begin{array}{r}>0.99^{\mathrm{s}} \\
0.02^{\mathrm{s}}\end{array}$ \\
\hline $\mathrm{BC}_{1 \mathrm{R}}(\mathrm{TM} \times \mathrm{PI})$ & & 1 & 30 & 22 & 11 & $1: 1$ & 0.80 & & 19 & 12 & 5 & $\begin{array}{l}1: 1 \\
1: 3\end{array}$ & $\begin{aligned} & 0.88^{\mathrm{s}} \\
< & 0.001^{\mathrm{s}}\end{aligned}$ & & 33 & 30 & 0 & $1: 1: 0$ & 0.63 \\
\hline
\end{tabular}

${ }^{\mathrm{z}} \mathrm{R}_{1}$, resistant, class $1 ; \mathrm{R}_{2,3}$, resistant, classes 2 and 3; $\mathrm{I}_{4-6}$, intermediate, classes 4-6; $\mathrm{S}_{7-9}$ susceptible, classes 7-9.

${ }^{\mathrm{y}} \mathrm{R}_{1-3}$, resistant, classes $1-3 ; \mathrm{I}_{4-6}$, intermediate, classes $4-6 ; \mathrm{S}_{7-9}$ susceptible, classes 7-9.

${ }^{\mathrm{x}}$ Presence $(+)$ or absence $(-)$.

"Parent or race differential phenotype: $\mathrm{R}=$ resistant, $\mathrm{S}=$ susceptible.

${ }^{\mathrm{v}} \mathrm{R}_{1}+\mathrm{R}_{2,3}: \mathrm{I}_{4-6}+\mathrm{S}_{7-9}$.

"Chi-square analysis.

${ }^{\mathrm{t}} \mathrm{R}_{1-3}: \mathrm{I}_{4-6}+\mathrm{S}_{7-9}$.

${ }^{\mathrm{s}}$ Yates correction.

Aphis gossypii (Boissot et al., 2000). These studies reveal three putatively new genes in PI 313970 for resistance to powdery mildew incited by $S$. fuliginea.

A recessive gene conditioned resistance against true leaf infection by race 1 . A recessive gene appeared to condition resistance to cotyledon infection by race 2 U.S., although a second recessive gene may be involved in the cotyledon reaction. A semi-dominant gene conditioned resistance to true leaf infection by race 2 U.S.

Whitaker and Pryor (1947) showed a highly significant correlation $(r>0.82, P$ $=0.01$ ) between the disease reactions of cotyledons, leaves, and stems, and used that information to hasten selection progress for resistance to race 2 (prior to differentiation of French and U.S. variants). Ferrière and Molot (1988) concluded in contrast that cotyledons were highly susceptible to race 2France and should be disregarded. Cohen and Eyal (1995) reported inconsistent reactions of cotyledons and true leaves to races 1 and 2 (variant undetermined) in a group of 36 melon cultivars. They observed correlations between the cotyledon and true leaf reactions in this group of cultivars of $\approx 0.64$ for race 1 and 0.71 or 0.84 for race 2, depending upon the type of true leaf test (growth chamber or field). Most of the 36 cultivars were consistent in their reactions, i.e., resistant cotyledons and leaves, or susceptible cotyledons and leaves. Eight had susceptible cotyledons with leaves resistant to race 1 ; three had susceptible cotyledons with leaves resistant to race 2 . Two cultivars had susceptible cotyledons and susceptible true leaves in a growth chamber test, but had resistant leaves in a field test for race 2. One cultivar had resistant cotyledons and resistant true leaves in a growth chamber test, but had susceptible leaves in a field test for race 2 . These results from different genotypes suggested the likelihood of separate genetic control of cotyledon and true leaf reactions to powdery mildew.

In the present study, the uniform susceptibility of cotyledons of PI 313970 and 'Top Mark' and their $\mathrm{F}_{1}, \mathrm{~F}_{2}$, and $\mathrm{BC}_{1}$ families to race 1 suggest that PI 313970 and 'Top Mark' may have the same allele for susceptibility of cotyledons to race 1. PI 313970 appeared to express linked genes for resistance of cotyledons and true leaves to race 2U.S. based upon a single recessive gene model for resistance of the cotyledons.

Two genes may be involved in the resistance of the cotyledons to race 2U.S. based on the $\mathrm{F}_{2}$ segregation $(P=0.15)$, but the $\mathrm{BC}_{\mathrm{R}}$ segregation for the two-gene model was unacceptable $(P<0.001)$. The $\mathrm{F}_{2}$ segregation was marginal $(P=0.03)$ for the single-gene model; with a one plant difference the chi-square test would have been acceptable $(P=0.05)$. Moreover, the $\mathrm{BC}_{\mathrm{R}}$ data fit the expected ratio at a high level of acceptance $(P=0.88)$ for the single-gene model. Although the simpler model appears adequate to explain the cotyledon data, more data would clarify the situation.

The genes in PI 313970 for resistance to infection of true leaves by races 1 and 2U.S. appear to be linked, but more data are needed to verify this observation. Differences in their expression, i.e., recessive vs. semi-dominant, suggest that they are distinct.

The level of resistance in PI 313970 to true leaf infection by race 1 in a growth chamber was lower than that exhibited by 'PMR 45', 'PMR 5', and PI 124111, but was similar to PI 124112 (Table 1). In contrast, PI 313970 exhibited a high level of resistance to infection of true leaves in a greenhouse by race 2U.S. (Table 1). This difference in reaction to races 1 and 2U.S. may be useful for monitoring powdery mildew populations and for indicating mixtures of races 1 and 2. PI 313970 could serve as a differential that provides a high level of resistance to race 2U.S. and a lower level of resistance to race 1 that permits limited growth with restricted sporulation.

In hops, two dominant, race-specific genes $\left(R_{1}\right.$ and $R_{2}$ ) conditioned immunity (Liyanage et al., 1973; Royle, 1978) to S. humuli. A third dominant gene in hops $\left(R_{B}\right)$ conditioned the resistant blister response to any isolate (race) of S. humuli in the late stages of infection in the absence of $R_{1}$ and $R_{2}$, and in the presence of $R_{1}$ (Liyanage et al., 1973; Royle, 1978). Resistant blisters in hops were largely limited to greenhouses and only observed in open fields under heavy inoculum loads (Salmon, 1917).

Resistant blisters on melon have thus far only been observed in response to infection by race 2U.S. in a greenhouse. Like hops, the resistant blisters on PI 313970 and PI 124111were not obvious until susceptible genotypes were heavily infected, and were expressed in the presence of other genes for resistance to races 1 and 2 . The resistant blister reaction has not been previously observed in PI 124111 (C.E. Thomas, personal communication)

Allelism tests with the known powdery mildew resistance genes must be done before these genes can be given permanent symbols. The recessive gene for resistance of true leaves to race 1 may be identical or allelic to the recessive gene for resistance to race 1 reported in line 92417, which is related to PI 414723 (McCreight et al., 1987, 1992). The semidominant gene for resistance of true leaves to race 2 U.S. may be identical or allelic to the semi-dominant gene in 'PMR 6', PI 124111, or PI 124112 (Kenigsbuch and Cohen, 1992). The recessive gene for resistance of cotyledons to race 2U.S. may be unique; no genes have been previously reported in melon for resistance of cotyledons to any of the described races. The resistant blister reaction in response to powdery mildew has not been previously reported on melon, and its inheritance remains to be determined. 


\section{Literature Cited}

Ballantyne, B. 1975. Powdery mildew on cucurbitaceae, identity, distribution, host range and sources of resistance. Proc. Linnean Soc. New South Wales 99:100-120.

Boissot, N., C. Pavis, R. Guillaume, D. Lafortune, and N. Sauvion. 2000. Insect resistance in Cucumis melo accession 90625, p. 297-304. In: N. Katzir and H.S. Paris (eds.). Proc. 7th EUCARPIA Mtg.on Cucurbit Genetics and Breeding. Ma'ale Ha Hamisha, Israel, ISHS, Belgium.

Cohen, Y. and H. Eyal. 1995. Differential expression of resistance to powdery mildew incited by race 1 or 2 of Sphaerotheca fuliginea in Cucumis melo genotypes at various stages of plant development. Phytoparasitica 23:223-230.

Ferriere, H. and P.M. Molot. 1988. Effect of leaf position on the susceptibility of melon plants to artificial infection with powdery mildew Sphaerotheca-fuliginea. J. Phytopathol. (Berl) 121:250-254.

Hosoya, K., M. Kuzuya, T. Murakami, K. Kato, K. Narisawa, and H. Ezura. 2000. Impact of resistant melon cultivars on Sphaerotheca fuliginea. Plant Breed. 119:286-288.
Kable, F.P. and J.B. Ballantyne. 1963. Observation on the cucurbit powdery mildew in the Ithaca district. Plant Dis. Rptr. 47:482.

Kenigsbuch, D. and Y. Cohen. 1992. Inheritance and allelism of genes for resistance to races 1 and 2 of Sphaerotheca fuliginea in muskmelon. Plant Dis. 76:626-629.

Liyanage, A.d.S., R.A. Neve, and D.J. Royle. 1973. Resistance to hop powdery mildew (Sphaerotheca humuli (DC.) Burr). Rpt. Dept. Hop Res. Wye College 1972, 49-50.

McCreight, J.D. 2000a. Inheritance of resistance to lettuce infectious yellows virus in melon. HortScience 35:1118-1120.

McCreight, J.D. 2000b. Molecular and phenotypic variation in melon PI313970, p. 235-239. In: N. Katzir and H. Paris (eds.). Proc. 7th EUCARPIA Mtg. on Cucurbit Genetics and Breeding, Ma'ale Ha Hamisha, Israel, ISHS, Belgium.

McCreight, J.D., G.W. Bohn, and A.N. Kishaba. 1992. 'Pedigree' PI 414723 melon. Cucurbit Genet. Coop. Rpt. 15:51-52.

McCreight, J.D., M. Pitrat, C.E. Thomas, A.N Kishaba, and G.W. Bohn. 1987. Powdery mildew resistance genes in muskmelon. J. Amer. Soc. Hort. Sci. 112:156-160.
Pitrat, M., C. Dogimont, and M. Bardin. 1998. Resistance to fungal diseases of foliage in melon, p. 167-173. In: J.D. McCreight (ed.). Cucurbitaceae '98: Evaluation and enhancement of cucurbit germplasm. ASHS Press, Alexandria, Va.

Royle, D.J. 1978. Powdery mildew of the hop, p. 381-409. In: D.M. Spencer (ed.). The powdery mildews. Academic, New York.

Salmon, E.S. 1917. On the resistance to fungicides shown by the hop-mildew (Sphaerotheca humuli (D.C.) Burr.) in different stages of development. Ann. Appl. Biol. 1:93-96.

Salmon, E.S. 1919. On forms of the hop (Humulus lupulus) resistant to mildew (Sphaerotheca humuli (DC.) Burr.); III. Ann. Appl. Biol. 5: 252-260.

Whitaker, T.W. and E.D. Pryor. 1947. Correlated resistance of leaves, cotyledons, and stems of Cucumis melo L. to cantaloupe powdery mildew (Erysiphe cichoracearum DC.). Phytopathology 37:865-867.

Yates, F. 1931. Contingency tables involving small numbers and the $\chi^{2}$ test. Suppl. J. Royal Stat. Soc. 1:215-235. 